Article

\title{
Coupling of epoxides and carbon dioxide catalyzed by Brönsted acid ionic liquids
}

\author{
Tao Chang a,*, Xiaorui Gao a , Li Bian a , Xiying Fu a, Mingxia Yuan a, Huanwang Jing b,\# \\ a Engineering Laboratory for Coalbed Gas Exploitation of Hebei Province, College of Science, Hebei University of Engineering, Handan 056038, Hebei, \\ China \\ b State Key Laboratory of Applied Organic Chemistry, College of Chemistry and Chemical Engineering, Lanzhou University, Lanzhou 730000, Gansu, China
}

\section{A R T I C L E I N F O}

Article history:

Received 11 August 2014

Accepted 15 September 2014

Published 20 March 2015

\section{Keywords:}

Carbon dioxide fixation

Coupling reaction

Brönsted acidic ionic liquid

Cyclic carbonate

Hammett acidity

\begin{abstract}
A B S T R A C T
A series of Brönsted acid ionic liquids (BAILs) containing a long chain Brönsted acid site in the cationic part and a Lewis basic site in the anionic part were designed, synthesized, and used as catalyst for the coupling of epoxides and carbon dioxide to cyclic carbonates without a co-catalyst or co-solvent. The effects of catalyst structure and other parameters on the catalytic performance were investigated. The long chain 2-(N,N-dimethyldodecylammonium) acetic acid bromide ([( $\left.\left.\left.\mathrm{CH}_{2} \mathrm{COOH}\right) \mathrm{DMDA}\right] \mathrm{Br}\right)$ showed high catalytic activity and good reusability. This protocol was expanded to various epoxides, which gave the corresponding cyclic carbonates in good yields. The acidity of the catalyst influenced its catalytic activity.
\end{abstract}

(c) 2015, Dalian Institute of Chemical Physics, Chinese Academy of Sciences. Published by Elsevier B.V. All rights reserved.

drogen bonding between the catalyst and epoxide may be the key factor in the coupling of epoxides and $\mathrm{CO}_{2}$. However, Brönsted acid ionic liquids (BAILs) with imidazolium as the cation are expensive, which hindered their industrial application. Furthermore, the commonly used dialkylimidazoliumbased ionic liquids showed negligible biodegradability. Thus, it is necessary to synthesize a less expensive ionic liquid. Meanwhile, the factors such as the structure and acidity of the catalyst have not been studied well. It was reported in our previous reports that the structure of the ionic liquid has an important influence on the catalytic activity [38-40]. Here, several novel long chain BAILs functionalized with a carboxyl group (Scheme 1) were synthesized. A detailed study of the effects of alkyl chain length and nucleophilicity of the anion on the coupling reaction and recycle performance was also conducted. To un-

\footnotetext{
*Corresponding author. Tel: +86-310-8578760; Fax: +86-310-6025698; E-mail: changt03@sina.com

\# Corresponding author. Tel: +86-931-8912585; Fax: +86-931-8912582; E-mail: hwjing@lzu.edu.cn

This work was supported by the Natural Science Foundation of Hebei Province (B2012402001) and the National Natural Science Foundation of China (51202054, 21173106).

DOI: 10.1016/S1872-2067(14)60227-8 | http://www.sciencedirect.com/science/journal/18722067 | Chin. J. Catal., Vol. 36, No. 3, March 2015
} 

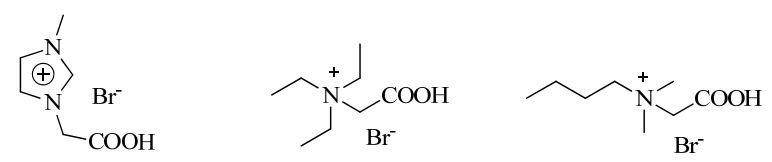

$\left[\left(\mathrm{CH}_{2} \mathrm{COOH}\right) \mathrm{MIM}\right] \mathrm{Br}(\mathbf{1}) \quad\left[\left(\mathrm{CH}_{2} \mathrm{COOH}\right) \mathrm{TEA}\right] \mathrm{Br}(\mathbf{2}) \quad\left[\left(\mathrm{CH}_{2} \mathrm{COOH}\right) \mathrm{DMBA}\right] \mathrm{Br}(\mathbf{3})$<smiles>CCCC(C)(C)CC(=O)O</smiles>

$$
\mathrm{Y}_{10}^{+} \mathrm{I}_{\mathrm{X}^{-}}^{\mathrm{N}} \mathrm{COOH}
$$

$\left[\left(\mathrm{CH}_{2} \mathrm{COOH}\right) \mathrm{DMOA}\right] \mathrm{Br}(\mathbf{4}) \quad\left[\left(\mathrm{CH}_{2} \mathrm{COOH}\right) \operatorname{DMDA}\right] \mathrm{X}(\mathbf{5 a} \mathbf{\mathrm { X }}=\mathrm{Br} ; \mathbf{5 b}: \mathrm{X}=\mathrm{Cl})$

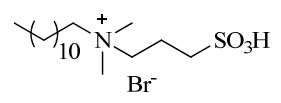

[(DDPA $] \mathrm{Br}(\mathbf{6})$

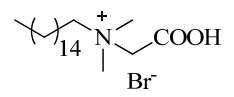

$\left[\left(\mathrm{CH}_{2} \mathrm{COOH}\right) \mathrm{DMHA}\right] \mathrm{Br}(7)$
Scheme 1. Structure of the Brönsted acid ionic liquids (BAILs).

derstand the relationship between acidity and activity, the Hammett method was used to evaluate the acidity of the BAILs.

\section{Experimental}

\subsection{Reagents and analysis}

1-Methylimidazole (99\%), triethylamine, $N, N$-dimethylbutylamine (97\%), $\mathrm{N}, \mathrm{N}$-dimethyloctylamine (95\%), $\mathrm{N}, \mathrm{N}$-dimethyldodecylamine(97\%), $N, N$-dimethylhexadecylamine $(97 \%)$, $p$-toluenesulfonic acid monohydrate, 1,3-propanesultone, methyl chloroacetate, and methyl bromoacetate were obtained from Aladdin Reagent Co. (Shanghai, China). Propylene oxide, epichlorohydrin, styrene oxide, butylene oxide, phenyl glycidyl ether, and epoxy cyclohexane were obtained from Energy Chemicals (Shanghai, China). The other reagents were purchased from Tianjin Kemio Fine Chemical Institute (China) and used without purification. NMR spectra were recorded on a Bruker $500 \mathrm{MHz}$ spectrometer. ESI-MS was performed on an Esquire 6000 mass spectrometer. The Hammett acidity of BAILs was measured using a PerkinElmer Lambda 35 UV/Vis spectrometer with a basic indicator as reported in our previous paper [39]. The melting point was determined on an XT-4 melting point apparatus without calibration.

\subsection{Catalyst preparation}

The BAILs were prepared according to reported procedures [41]. A typical synthesis route of [ $\left.\left(\mathrm{CH}_{2} \mathrm{COOH}\right) \mathrm{DMDA}\right] \mathrm{Br}$ (5a) is as follows. Under an inert atmosphere of $\mathrm{N}_{2}$, a mixture of $\mathrm{N}, \mathrm{N}$-dimethyldodecylamine (0.01 mol, $1.27 \mathrm{~mL}$ ) and methyl bromoacetate $(0.01 \mathrm{~mol}, 0.6 \mathrm{~mL})$ was stirred at room temperature for $12 \mathrm{~h}$, during which time the reaction mixture turned into a solid. A mixture of the solid and $\mathrm{HCl}\left(37 \% \mathrm{H}_{2} \mathrm{O}\right.$ solution, $0.012 \mathrm{~mol}$ ) was refluxed for $1 \mathrm{~h}$. The solvent was removed under vacuum, and the remaining solid was washed three times with cold diethyl ether to give the product as a white powder.

$\left[\left(\mathrm{CH}_{2} \mathrm{COOH}\right) \mathrm{TEA}\right] \mathrm{Br}(2) \cdot \mathrm{mp} 188-190^{\circ} \mathrm{C}$, yield $86 \%$, a white solid; ${ }^{1} \mathrm{H}$ NMR (500 M, $\left.{ }_{2} \mathrm{O}\right): \delta=1.12$ (dd, $J=7.5 \mathrm{~Hz}, 9 \mathrm{H}$,
$\mathrm{CH}_{3} \mathrm{CH}_{2}-$ ), 3.36-3.40 (m, 6H, $\left.\mathrm{CH}_{2} \mathrm{~N}\right), 3.89$ (s, $\left.2 \mathrm{H}, \mathrm{NCH} 2 \mathrm{COOH}\right) ;{ }^{1} \mathrm{C}$ NMR (125 M, $\left.\mathrm{D}_{2} \mathrm{O}\right): \delta=7.02,54.20,55.37,167.34$; ESI-MS: calcd for $\mathrm{C}_{8} \mathrm{H}_{18} \mathrm{NO}_{2} \mathrm{Br} m / z[\mathrm{M}]^{+}=160.2$, found 160.3 .

[( $\left.\left.\mathrm{CH}_{2} \mathrm{COOH}\right) \mathrm{DMBA}\right] \mathrm{Br}$ (3). mp $156-158{ }^{\circ} \mathrm{C}$, yield $90 \%$, a white solid; ${ }^{1} \mathrm{H}$ NMR (500 M, $\left.\mathrm{D}_{2} \mathrm{O}\right): \delta=0.76(\mathrm{dd}, J=7.5 \mathrm{~Hz}, 3 \mathrm{H}$, $\mathrm{CH}_{3} \mathrm{CH}_{2}-$ ), 1.16-1.23 (m, $2 \mathrm{H}, \mathrm{CH}_{3} \mathrm{CH}_{2} \mathrm{CH}_{2} \mathrm{CH}_{2} \mathrm{~N}$ ), 1.53-1.69 (m, $2 \mathrm{H}, \mathrm{CH}_{3} \mathrm{CH}_{2} \mathrm{CH}_{2} \mathrm{CH}_{2} \mathrm{~N}$ ), 3.07 (s, $6 \mathrm{H}, \mathrm{NCH}_{3}$ ), 3.86 (dd, $\mathrm{J}=8.5 \mathrm{~Hz}$, $2 \mathrm{H}, \mathrm{CH}_{2} \mathrm{CH}_{2} \mathrm{~N}$ ), 3.97 (s, 2H, NCH $\mathrm{CHOH}_{2} \mathrm{COO}{ }^{1} \mathrm{C} \mathrm{NMR}\left(125 \mathrm{M}, \mathrm{D}_{2} \mathrm{O}\right)$ : $\delta=12.91,19.11,24.13,51.57,65.41,167.50$; ESI-MS: calcd for $\mathrm{C}_{8} \mathrm{H}_{18} \mathrm{NO}_{2} \mathrm{Br} m / z[\mathrm{M}]^{+}=160.2$, found 160.3 .

[( $\left.\left.\mathrm{CH}_{2} \mathrm{COOH}\right) \mathrm{DMOA}\right] \mathrm{Br}$ (4). mp 134-135 ${ }^{\circ} \mathrm{C}$, yield $92 \%$, a white solid; ${ }^{1} \mathrm{H}$ NMR (500 M, D $\left.{ }_{2} \mathrm{O}\right): \delta=0.68(\mathrm{dd}, J=7.0 \mathrm{~Hz}, 3 \mathrm{H}$, $\mathrm{CH}_{3} \mathrm{CH}_{2}-$ ), $1.10-1.18\left(\mathrm{~m}, 10 \mathrm{H}, \mathrm{CH}_{3}\left(\mathrm{CH}_{2}\right)_{5} \mathrm{CH}_{2} \mathrm{CH}_{2} \mathrm{~N}\right.$ ), 1.59 (dd, $\mathrm{J}=$ $\left.8.5 \mathrm{~Hz}, 2 \mathrm{H},-\mathrm{CH}_{2} \mathrm{CH}_{2} \mathrm{~N}\right), 3.07(\mathrm{~s}, 6 \mathrm{H}, \mathrm{NCH}), 3.34-3.37(\mathrm{~m}, 2 \mathrm{H}$, $\mathrm{CH}_{2} \mathrm{CH}_{2} \mathrm{~N}$ ), 3.99 (s, 2H, NCH${ }_{2} \mathrm{COOH}$ ); ${ }^{1} \mathrm{C}$ NMR (125 M, D $\mathrm{D}_{2} \mathrm{O}$ ): $\delta=$ 13.64, 22.22, 25.58, 28.36, 31.20, 51.71, 65.37, 167.21; ESI-MS: calcd for $\mathrm{C}_{12} \mathrm{H}_{26} \mathrm{NO}_{2} \mathrm{Br} m / z$ [M] ${ }^{+}=216.3$, found 216.3 .

[(CH $2 \mathrm{COOH}) \mathrm{DMDA}] \mathrm{Br}$ (5a). mp $140-141{ }^{\circ} \mathrm{C}$, yield 95\%, a white solid; ${ }^{1} \mathrm{H}$ NMR (500 M, $\left.\mathrm{D}_{2} \mathrm{O}\right): \delta=0.70\left(\mathrm{~d}, 3 \mathrm{H}, \mathrm{CH}_{3} \mathrm{CH}_{2}-\right.$ ), 1.16 (d, 20H, $\left.\mathrm{CH}_{3}\left(\mathrm{CH}_{2}\right)_{10} \mathrm{CH}_{2} \mathrm{CH}_{2} \mathrm{~N}\right), 1.59$ (s, $\left.2 \mathrm{H},-\mathrm{CH}_{2} \mathrm{CH}_{2} \mathrm{~N}\right), 3.11$ (s, 6H, NCH3), $3.47\left(\mathrm{~m}, 2 \mathrm{H}, \mathrm{CH}_{2} \mathrm{CH}_{2} \mathrm{~N}\right.$ ), $3.92(\mathrm{~s}, 2 \mathrm{H}, \mathrm{NCH} 2 \mathrm{COOH})$; ${ }^{1} \mathrm{C}$ NMR (125 M, $\left.\mathrm{D}_{2} \mathrm{O}\right): \delta=14.01,22.72,22.82,26.41,29.30$, 29.69, 29.81, 29.90, 30.00, 30.07, 32.16, 52.12, 63.96, 167.50; ESI-MS: calcd for $\mathrm{C}_{16} \mathrm{H}_{34} \mathrm{NO}_{2} \mathrm{Br} m / z[\mathrm{M}]^{+}=272.4$, found 272.4 .

$\left[\left(\mathrm{CH}_{2} \mathrm{COOH}\right) \mathrm{DMDA}\right] \mathrm{Cl}$ (5b). mp $150-152{ }^{\circ} \mathrm{C}$, yield 95\%, a white solid; ${ }^{1} \mathrm{H}$ NMR (500 M, $\left.\mathrm{D}_{2} \mathrm{O}\right): \delta=0.66\left(\mathrm{t}, 3 \mathrm{H}, \mathrm{CH}_{3} \mathrm{CH}_{2}-\right.$ ), $1.12\left(\mathrm{t}, 2 \mathrm{OH}, \mathrm{CH}_{3}\left(\mathrm{CH}_{2}\right)_{10} \mathrm{CH}_{2} \mathrm{CH}_{2} \mathrm{~N}\right), 1.53\left(\mathrm{~d}, 2 \mathrm{H},-\mathrm{CH}_{2} \mathrm{CH}_{2} \mathrm{~N}\right), 3.06$ (s, 6H, NCH$), 3.41\left(\mathrm{t}, 2 \mathrm{H}, \mathrm{CH}_{2} \mathrm{CH}_{2} \mathrm{~N}\right), 3.91\left(\mathrm{~s}, 2 \mathrm{H}, \mathrm{NCH} \mathrm{COOH}_{3} ;{ }^{1} \mathrm{C}\right.$ NMR (125 M, $\mathrm{D}_{2} \mathrm{O}$ ): $\delta=14.01,22.72,22.82,26.41,29.30,29.69$, 29.81, 29.90, 30.00, 30.07, 32.16, 52.12, 63.96, 167.50; ESI-MS: calcd for $\mathrm{C}_{16} \mathrm{H}_{34} \mathrm{NO}_{2} \mathrm{Cl} \mathrm{m} / z[\mathrm{M}]^{+}=272.4$, found 272.4 .

[DDPA]Br (6). mp $164-165^{\circ} \mathrm{C}$, yield $96 \%$, a white solid; ${ }^{1} \mathrm{H}$ NMR (500 M, D 20$): \delta=0.65\left(\mathrm{t}, 3 \mathrm{H}, \mathrm{CH}_{3} \mathrm{CH}_{2}-\right), 1.06(\mathrm{~s}, 16 \mathrm{H}$, $\mathrm{CH}_{3}\left(\mathrm{CH}_{2}\right)_{8} \mathrm{CH}_{2} \mathrm{CH}_{2} \mathrm{~N}$ ), 1.15 (s, $2 \mathrm{H},-\mathrm{CH}_{2} \mathrm{CH}_{2} \mathrm{CH}_{2} \mathrm{~N}$ ), 1.54 (s, $2 \mathrm{H}$, $-\mathrm{CH}_{2} \mathrm{CH}_{2} \mathrm{~N}$ ), 1.94-2.00 (m, $2 \mathrm{H}, \mathrm{NCH}_{2} \mathrm{CH}_{2} \mathrm{CH}_{2} \mathrm{SO}_{3} \mathrm{H}$ ), $2.71(\mathrm{t}, 2 \mathrm{H}$, $\mathrm{NCH}_{2} \mathrm{CH}_{2} \mathrm{CH}_{2} \mathrm{SO}_{3} \mathrm{H}$ ), 2.91 (s, $\left.6 \mathrm{H}, \mathrm{NCH}\right), 3.13\left(\mathrm{t}, 2 \mathrm{H},-\mathrm{CH}_{2} \mathrm{CH}_{2} \mathrm{~N}\right.$ ), 3.25-3.28 (m, $2 \mathrm{H}, \mathrm{NCH}_{2} \mathrm{CH}_{2} \mathrm{CH}_{2} \mathrm{SO}_{3} \mathrm{H}$ ); ${ }^{1} \mathrm{C}$ NMR (125 M, $\left.\mathrm{D}_{2} \mathrm{O}\right): \delta$ = 13.99, 18.44, 22.41, 22.79, 26.25, 29.26, 29.67, 29.76, 29.90, 29.99, 30.04, 32.12, 47.51, 50.77, 62.22, 64.32; ESI-MS: calcd for $\mathrm{C}_{17} \mathrm{H}_{38} \mathrm{NSO}_{3} \mathrm{Br} m / z[\mathrm{M}]^{+}=336.6$, found 336.5 .

[( $\left.\left.\mathrm{CH}_{2} \mathrm{COOH}\right) \mathrm{DMHA}\right] \mathrm{Br}$ (7). mp $146-147{ }^{\circ} \mathrm{C}$, yield 93\%, a white solid; ${ }^{1} \mathrm{H}$ NMR (500 M, DMSO): $\delta=0.84\left(\mathrm{t}, 3 \mathrm{H}, \mathrm{CH}_{3} \mathrm{CH}_{2}-\right.$ ), 1.22 (s, 28, $\left.\mathrm{CH}_{3}\left(\mathrm{CH}_{2}\right)_{14} \mathrm{CH}_{2} \mathrm{CH}_{2} \mathrm{~N}\right), 1.63\left(\mathrm{~s}, 2 \mathrm{H},-\mathrm{CH}_{2} \mathrm{CH}_{2} \mathrm{~N}\right.$ ), 2.44-2.49 (m, 6H, NCH$), 3.21\left(\mathrm{t}, 2 \mathrm{H}, \mathrm{CH}_{2} \mathrm{CH}_{2} \mathrm{~N}\right), 3.34-3.74(\mathrm{~m}$, $2 \mathrm{H}, \mathrm{NCH} \mathrm{COOH}_{2}$; ESI-MS: calcd for $\mathrm{C}_{20} \mathrm{H}_{42} \mathrm{NO}_{2} \mathrm{Br} \mathrm{m} / z[\mathrm{M}]^{+}=$ 328.6, found 328.6.

\subsection{Hammett acidity of the BAILs}

The Hammett acidity $\left(H_{0}\right)$ function was calculated by the equation: $H_{0}=\mathrm{p} K(\mathrm{Iaq})+\lg \left([\mathrm{I}]_{\mathrm{s}} /\left[\mathrm{IH}^{+}\right]_{\mathrm{s}}\right)$. Here, "I" represents the base indicator, and $\left[\mathrm{IH}^{+}\right]_{\mathrm{s}}$ and $[\mathrm{I}]_{\mathrm{s}}$ are, respectively, the molar concentration of the protonated and non-protonated forms of the indicator. The value of $[\mathrm{I}]_{\mathrm{s}} /\left[\mathrm{IH}^{+}\right]_{\mathrm{s}}$ was determined and calculated from the UV-Vis spectrum. In the experiment, dimethyl yellow ( $\mathrm{p} K_{\mathrm{a}}=3.3$ ) was chosen as the base indicator and ethanol as the solvent. The maximum absorbance of the non-protonat- 
ed form of dimethyl yellow was observed at $432.5 \mathrm{~nm}$ in ethanol. With the increase in acidity of the BAILs, the absorbance of the non-protonated form of the base indicator decreased, while the protonated form of the indicator could not be observed because of its small molar absorptivity. So $[\mathrm{I}]_{\mathrm{S}} /\left[\mathrm{IH}^{+}\right]_{\mathrm{s}}$ was determined from the difference in measured absorbance after the addition of catalyst, and then $H_{0}$ can be calculated.

\subsection{General procedure for the coupling of epoxide and $\mathrm{CO}_{2}$ catalyzed by BAILs}

A solution of BAIL $(0.1 \mathrm{mmol})$ in epoxide $(0.1 \mathrm{~mol})$ was introduced into a $100 \mathrm{~mL}$ stainless steel autoclave. It was purged three times with $\mathrm{CO}_{2}$ and then filled with $\mathrm{CO}_{2}$ to $0.9 \mathrm{MPa}$ at room temperature. Then, the mixture was stirred and heated to $120^{\circ} \mathrm{C}$. After the reaction, the reactor was cooled and vented. The remaining mixture was distilled under reduced pressure or recrystallized with ethanol to obtain the pure cyclic carbonate.

4,5-Tetramethylene-1,3-dioxolan-2-one. ${ }^{1} \mathrm{H}$ NMR (500 M, $\left.\mathrm{CDCl}_{3}\right): \delta=1.38-1.43(\mathrm{~m}, 2 \mathrm{H}), 1.56-1.61(\mathrm{~m}, 2 \mathrm{H}), 1.86-1.89(\mathrm{~m}$, $4 \mathrm{H}), 4.66-4.68(\mathrm{~m}, 2 \mathrm{H}) ;{ }^{1} \mathrm{C}$ NMR $\left(125 \mathrm{M}, \mathrm{CDCl}_{3}\right): \delta=19.39$, $26.99,76.02,155.84$.

\section{Results and discussion}

\subsection{Hammett acidity function-activity relationship}

The $H_{0}$ function expresses the acidity strength of an acid in an organic solvent. The $H_{0}$ of the BAILs is listed in Table 1 . Unfortunately two ionic liquids showed no protonation, but the other results effectively distinguished the acidity of the various ionic liquids. The Brönsted acidity of the BAILs with different cations was determined (entries 2-5, 7, and 8). The acidity of the BAILs followed the order $\mathbf{6}>\mathbf{7}>\mathbf{5 a}>\mathbf{4}>\mathbf{2}$, which clearly indicated that the length of the carbon chain in the cation influenced the acidity of the BAILs. A longer carbon chain in the catalyst gave a stronger acidity, which was in agreement with our previous reported work (entries 2-5 and 8) [38-40]. It was postulated that an increase in the bulkiness of the alkyl chain results in a decrease in the electrostatic interaction between the cation and anion, consequently, the acidity increased [36]. Also, the acidity order was correlated with the order of the

Table 1

$H_{0}$ of the BAILs and their activity for the coupling of epichlorohydrin with $\mathrm{CO}_{2}$.

\begin{tabular}{lccc}
\hline Entry & BAILs & $H_{0}$ & Yield (\%) \\
\hline 1 & {$\left[\left(\mathrm{CH}_{2} \mathrm{COOH}\right) \mathrm{MIM}\right] \mathrm{Br}(\mathbf{1})$} & $\mathrm{Np}$ & 20.5 \\
2 & {$\left[\left(\mathrm{CH}_{2} \mathrm{COOH}\right) \mathrm{TEA}\right] \mathrm{Br}(\mathbf{2})$} & 4.39 & 38.1 \\
3 & {$\left[\left(\mathrm{CH}_{2} \mathrm{COOH}\right) \mathrm{DMBA}\right] \mathrm{Br}(\mathbf{3})$} & $\mathrm{Np}$ & 37.4 \\
4 & {$\left[\left(\mathrm{CH}_{2} \mathrm{COOH}\right) \mathrm{DMOA}\right] \mathrm{Br}(\mathbf{4})$} & 4.26 & 45.4 \\
5 & {$\left[\left(\mathrm{CH}_{2} \mathrm{COOH}\right) \mathrm{DMDA}\right] \mathrm{Br}(\mathbf{5 a})$} & 4.03 & 48.4 \\
$6^{\mathrm{a}}$ & {$\left[\left(\mathrm{CH}_{2} \mathrm{COOH}\right) \mathrm{DMDA}\right] \mathrm{Cl}(\mathbf{5 b})$} & 4.70 & 42.5 \\
$7^{\mathrm{a}}$ & {$[\mathrm{DDPA}] \mathrm{Br}(\mathbf{6})$} & 2.51 & 16.8 \\
8 & {$\left[\left(\mathrm{CH}_{2} \mathrm{COOH}\right) \mathrm{DMHA}\right] \mathrm{Br}(\mathbf{7})$} & 3.65 & 49.8 \\
\hline
\end{tabular}

Conditions for UV-Vis spectrum measurement: solvent ethanol, indicator dimethyl yellow ( $\left.\mathrm{p} K_{\mathrm{a}}=3.3,54 \mu \mathrm{mol} / \mathrm{L}\right)$, BAILs $30 \mathrm{mmol} / \mathrm{L}, 25^{\circ} \mathrm{C}$. Reaction conditions: epichlorohydrin (ECH) $0.1 \mathrm{~mol}$, catalyst $1 \mathrm{~mol} \%, T$ $=100^{\circ} \mathrm{C}, p=0.9 \mathrm{MPa}, t=0.5 \mathrm{~h} .{ }^{\mathrm{a}} 120^{\circ} \mathrm{C}$. Np: No protonation.
BAILs catalytic activity for the coupling reaction. The BAIL of 6 incorporated with a sulfonic acidic group instead of a carboxylic one showed the strongest acidity (entry 7 versus entries 2-6 and 8). However, 6 exhibited the lowest activity even at a high temperature (entry 7). The result implied that moderate acidity was beneficial for the reaction. According to the reaction mechanism, hydrogen bonding between the proton of the carbonyl group and oxygen of the epoxide has a positive effect on activating the ring opening of the epoxide. However, hydrogen bonding that is too strong, formed when the acidity of the ionic liquid was strong, impeded the insertion of $\mathrm{CO}_{2}$ into the hydrogen bond between the hydrogen atom and oxygen atom [35]. Moreover, we propose that the long chain catalysts $\mathbf{5 a}$ and $\mathbf{7}$ have the ability to increase the solubility of $\mathrm{CO}_{2}$. Zhang et al. [42] reported that the solubility of $\mathrm{CO}_{2}$ increased with the length of the polyethoxyl chain. Hence, considering the cost, we selected $\mathbf{5 a}$ as a model catalyst for further investigation.

\subsection{Effect of reaction temperature on the coupling reaction}

The effect of reaction temperature on the coupling reaction of ECH and $\mathrm{CO}_{2}$ is shown in Fig. 1. The catalytic activity was sensitive to temperature. The yield increased sharply when the temperature increased from $60{ }^{\circ} \mathrm{C}$ to $120^{\circ} \mathrm{C}$. Further temperature increase had no significant effect on the conversion with a slight decrease of the yield because of side reactions [43]. Therefore, the optimum reaction temperature is $120^{\circ} \mathrm{C}$.

\subsection{Effect of catalyst amount on the coupling reaction}

The catalyst amount was also of great importance for the coupling reaction. The effect of the molar ratio of the catalyst on the reaction illustrated that there were not enough active sites for the reaction when the catalyst amount was low (Fig. 2). The yield increased with the catalyst amount from $0.2 \mathrm{~mol} \%$ to $0.8 \mathrm{~mol} \%$, and the yield remained constant when the molar ratio was above $1.0 \mathrm{~mol} \%$. On further increase in the amount of catalyst, the yield decreased slightly, therefore, $1 \mathrm{~mol} \%$ was selected as the best catalyst amount.

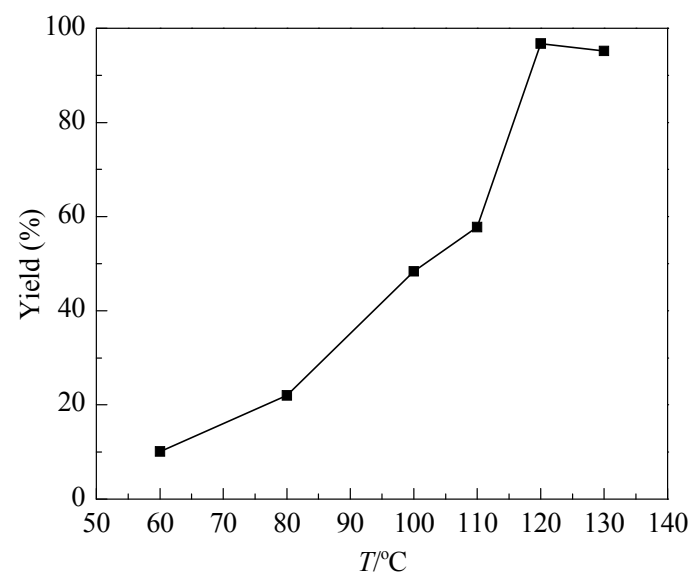

Fig. 1. Effect of reaction temperature on the coupling reaction in the presence of 5a. Reaction conditions: ECH $0.1 \mathrm{~mol}$, 5a $1 \mathrm{~mol} \%, p=0.9$ $\mathrm{MPa}, t=0.5 \mathrm{~h}$. 


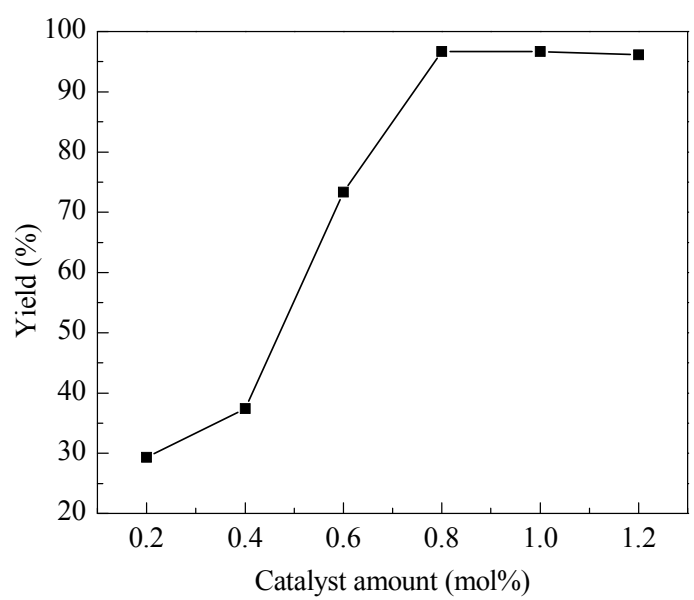

Fig. 2. Effect of catalyst amount on the coupling reaction with catalyst 5a. Reaction conditions: ECH $0.1 \mathrm{~mol}, p=0.9 \mathrm{MPa}, t=0.5 \mathrm{~h}$.

\subsection{Reusability of $\mathbf{5 a}$ for the coupling reaction}

It is well known that the stability and reusability of a catalyst system are two key factors that identify whether it can be applied in industry. To test these characteristics for the catalyst system, the coupling reaction was carried out under the optimum conditions with the best catalyst 5a. After the reaction, the catalyst was separated from the volatile organic products and starting materials by distillation and reused for the next cycle. As shown in Fig. 3, after five successive recycles, no significant drop in the yield was detected.

\subsection{Cyclic carbonate synthesis from various epoxides and $\mathrm{CO}_{2}$ catalyzed by $\mathbf{5 a}$}

To further extend the scope of the reaction, several other epoxides were utilized as the substrate in the coupling reaction in the presence of the best catalyst $\mathbf{5 a}$. The results are summarized in Table 2. The cyclic carbonates were synthesized with yields from good to excellent (entries 1-6). Aliphatic epoxides were preferred substrates for the reaction (entries 1-3 and 5),

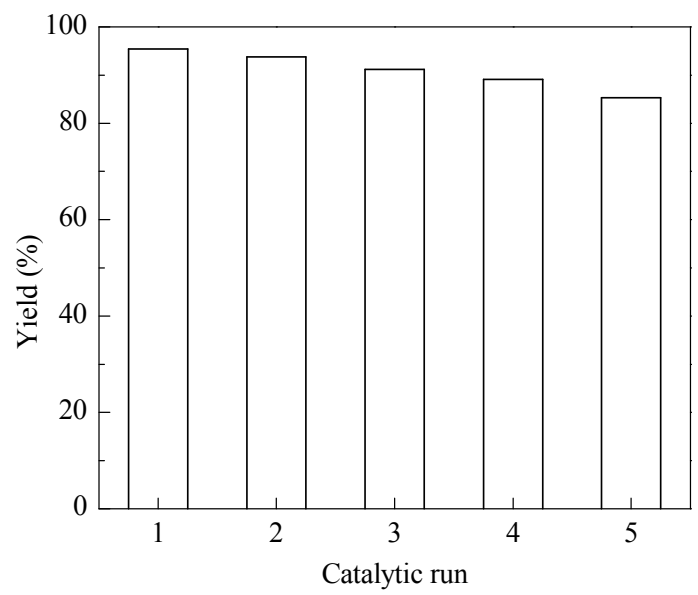

Fig. 3. Reusability of catalyst $\mathbf{5 a}$ for the coupling reaction. Reaction conditions: ECH $0.1 \mathrm{~mol}$, catalyst $5 \mathrm{a} 1 \mathrm{~mol} \%, p=0.9 \mathrm{MPa}, t=0.5 \mathrm{~h}$.
Table 2

Synthesis of other cyclic carbonates catalyzed by $\mathbf{5 a}$.

\begin{tabular}{lccccc}
\hline Entry & Substrate & Product & $t(\mathrm{~h})$ & Yield (\%) & TOF \\
\hline & & & & \\
\end{tabular}

in particular, the reaction of $\mathrm{ECH}$ and $\mathrm{CO}_{2}$ was completed within 30 min (entry 2). Aromatic epoxides, due to hindrance from the phenyl group, need a longer reaction time to reach a good conversion (entry 4). A more hindered epoxide needs a longer reaction time (entry 6). It can be seen that the steric effect is very important in this coupling reaction.

\subsection{Mechanism for the BAIL-catalyzed coupling reaction}

A mechanism for the BAIL-catalyzed coupling of epoxides with $\mathrm{CO}_{2}$ in accordance with previous reports [29-37] is proposed in Scheme 2. The Brönsted acid center of the catalyst activates the epoxide through a hydrogen bonding interaction. The Lewis basic center (bromide anion) attacks the activated carbon of the epoxide leading to ring opening to generate the alkoxide intermediate. Finally, the alkoxide intermediate un-

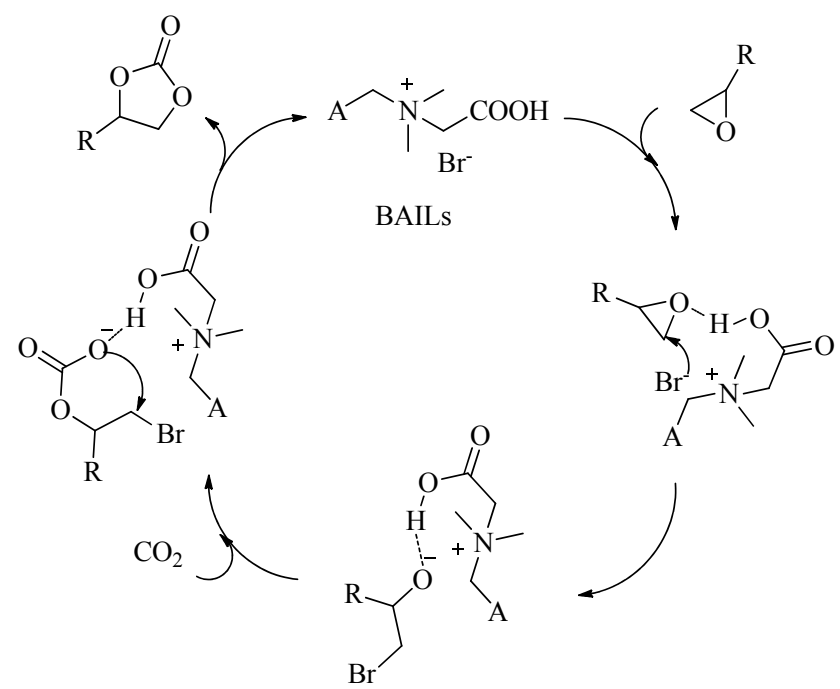

Scheme 2. Proposed mechanism for the BAIL-catalyzed coupling reaction. 
dergoes the insertion of $\mathrm{CO}_{2}$ and subsequent ring closure to form the cyclic carbonate along with the regeneration of the catalyst.

\section{Conclusions}

Long chain BAILs are efficient catalysts for the coupling of epoxides and $\mathrm{CO}_{2}$. They are easy to synthesize and are thermally stable and environmentally benign. The relationship between the acidity and catalytic activity of the catalyst was investigated. [( $\left.\left.\mathrm{CH}_{2} \mathrm{COOH}\right) \mathrm{DMDA}\right] \mathrm{Br}$ with moderate acidity and a long carbon chain exhibited the best activity, and it can be reused at least five times without loss of activity.

\section{References}

[1] Markewitz P, Kuckshinrichs W, Leitner W, Linssen J, Zapp P, Bongartz R, Schreiber A, Müller T E. Energy Environ Sci, 2012, 5: 7281

[2] Li L, Zhao N, Wei W, Sun Y H. Fuel, 2013, 108: 112

[3] Li H, Bhadury P S, Song B A, Yang S. RSC Adv, 2012, 2: 12525

[4] Fan Q J, Liu J H, Chen J, Xia C G. Chin J Catal (樊启佳, 刘建华, 陈静, 夏春谷. 催化学报), 2012, 33: 1435

[5] Castro-Osma J A, Lara-Sánchez A, North M, Otero A, Villuendas P. Catal Sci Technol, 2012, 2: 1021

[6] Lu X B, Darensbourg D J. Chem Soc Rev, 2012, 41: 1462

[7] Ren W M, Wu G P, Lin F, Jiang J Y, Liu C, Luo Y, Lu X B. Chem Sci, 2012, 3: 2094

[8] Beattie C, North M. Chem Eur J, 2014, 20: 8182

[9] Xie Y, Wang T T, Yang R X, Huang N Y, Zou K, Deng W Q. ChemSusChem, 2014, 7: 2110

[10] Iksi S, Aghmiz A, Rivas R, González M D, Cuesta-Aluja L, Castilla J Orejón A, Guemmout F E, Masdeu-Bultó A M. J Mol Catal A, 2014, 383-384: 143

[11] Li B, Zhang L L, Song Y Y, Bai D S, Jing H W. J Mol Catal A, 2012, 363-364: 26

[12] Bai D S, Duan S H, Hai L, Jing H W. ChemCatChem, 2012, 4: 1752

[13] Ema T, Miyazaki Y, Koyama S, Yano Y, Sakai T. Chem Commun, 2012, 48: 4489

[14] Wei R J, Zhang X H, Du B Y, Fan Z Q, Qi G R. J Mol Catal A, 2013, 379: 38
[15] Tharun J, Hwang Y, Roshan R, Ahn S, Kathalikkattil A C, Park D W. Catal Sci Technol, 2012, 2: 1674

[16] Li C Y, Wu C R, Liu Y C, Ko B T. Chem Commun, 2012, 48: 9628

[17] Roeser J, Kailasam K, Thomas A. ChemSusChem, 2012, 5: 1793

[18] Dai W L, Jin B, Luo S L, Luo X B, Tu X M, Au C T. Catal Today, 2014, 233: 92

[19] Chen J X, Jin B, Dai W L, Deng S L, Cao L R, Cao Z J, Luo S L, Luo X B, Tu X M, Au C T. Appl Catal A, 2014, 484: 26

[20] Yu T, Weiss R G. Green Chem, 2012, 14: 209

[21] Gao J, Song Q W, He L N, Liu C, Yang Z Z, Han X, Li X D, Song Q C. Tetrahedron, 2012, 68: 3835

[22] He Q, O’Brien J W, Kitselman K A, Tompkins L E, Curtis G C T, Kerton F M. Catal Sci Technol, 2014, 4: 1513

[23] Ghazali-Esfahani S, Song H B, Pâunescu E, Bobbink F D, Liu H Z, Fei Z F, Laurenczy G, Bagherzadeh M, Yan N, Dyson P J. Green Chem, 2013, 15: 1584

[24] Dai W L, Jin B, Luo S L, Luo X B, Tu X M, Au C T. J Mol Catal A, 2013, 378: 326

[25] Song Q W, He L N, Wang J Q, Yasuda H, Sakakura T. Green Chem, 2013, 15: 110

[26] Tharun J, Kim D W, Roshan R, Hwang Y, Park D W. Catal Commun, 2013, 31: 62

[27] Wong W L, Lee L Y S, Ho K P, Zhou Z Y, Fan T, Lin Z Y, Wong K Y. Appl Catal A, 2014, 472: 160

[28] Wang F, Xu C Z, Li Z, Xia C G, Chen J. J Mol Catal A, 2014, 385: 133

[29] Dai W L, Jin B, Luo S L, Luo X B, Tu X M, Au C T. Appl Catal A, 2014, 470: 183

[30] Xiao L F, Sun D, Yue C T, Wu W. J CO ${ }_{2}$ Utilization, 2014, 6: 1

[31] Dai W L, Jin B, Luo S L, Yin S F, Luo X B, Au C T. J CO $\mathrm{CO}_{2}$ Utilization, 2013, 3-4: 7

[32] Sun J, Wang J Q, Cheng W G, Zhang J X, Li X H, Zhang S J, She Y B. Green Chem, 2012, 14: 654

[33] Watile R A, Deshmukh K M, Dhake K P, Bhanage B M. Catal Sci Technol, 2012, 2: 1051

[34] Qu J, Cao C Y, Dou Z F, Liu H, Yu Y, Li P, Song W G. ChemSusChem, 2012, 5: 652

[35] Xiao L F, Lü D W, Su D, Wu W, Li H F. J Clean Prod, 2014, 67: 285

[36] Han L N, Choi S J, Park M S, Lee S M, Kim Y J, Kim M I, Liu B Y, Park D W. React Kinet Mech Catal, 2012, 106: 25

[37] Zhang Y Y, Yin S F, Luo S L, Au C T. Ind Eng Chem Res, 2012, 51: 3951

\section{Graphical Abstract}

Chin. J. Catal., 2015, 36: 408-413 doi: 10.1016/S1872-2067(14)60227-8

\section{Coupling of epoxides and carbon dioxide catalyzed by Brönsted acid ionic liquids}

Tao Chang*, Xiaorui Gao, Li Bian, Xiying Fu, Mingxia Yuan, Huanwang Jing*

Hebei University of Engineering; Lanzhou University

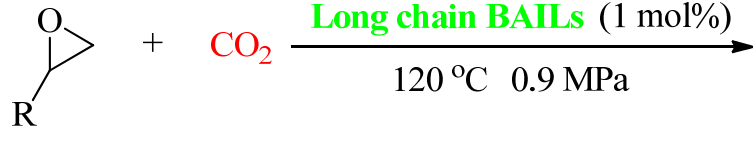

Yield: $81.2 \%-96.7 \%$<smiles>[R]C1COC(=O)O1</smiles><smiles>[X]C(C)(CCCC)[N+](C)(C)CC(=O)O</smiles>

$n=2,6,10,14 ; \mathrm{X}=\mathrm{Cl}, \mathrm{Br}$

Long chain BAILs

Brönsted acid ionic liquids were synthesized and gave high catalytic activity for the coupling of epoxides and $\mathrm{CO}_{2}$ under mild conditions without an organic solvent. The acidity of the catalyst influenced the activity. 
[38] He L Q, Qin S J, Chang T, Sun Y Z, Zhao J Q. Int J Mol Sci, 2014, 15: 8656

[39] He L Q, Qin S J, Chang T, Sun Y Z, Gao X R. Catal Sci Technol, 2013, 3: 1102

[40] Chang T, He L Q, Bian L, Han H Y, Yuan M X, Gao X R. RSC Adv, 2014, 4: 727
[41] Fei Z F, Zhao D B, Geldbach T J, Scopelliti R, Dyson P J. Chem Eur J, 2004, 10: 4886

[42] Zhang J L, Han B X, Zhao Y J, Li J S, Hou M Q, Yang G Y. Chem Commun, 2011, 47: 1033

[43] Miao C X, Wang J Q, Wu Y, Du Y, He L N. ChemSusChem, 2008, 1: 236

\title{
新型Brönsted酸性离子液体催化二氧化碳与环氧化合物偶联反应
}

\author{
常 涛 ${ }^{\mathrm{a},}$, 高晓荵, 边 丽 ${ }^{\mathrm{a}}$, 付西英 ${ }^{\mathrm{b}}$, 袁明霞 ${ }^{\mathrm{a}}$, 景欢旺, \\ a河北工程大学理学院, 河北省煤层气开发利用工程实验室, 河北邯単056038 \\ $\mathrm{b}^{\mathrm{E}}$ 州大学化学化工学院, 功能有机分子化学国家重点实验室, 甘肃兰州730000
}

摘要: 设计合成了一系列由碳链长度可调节的Brönsted酸中心阳离子及Lewis碱中心阴离子构成的酸性离子液体, 并应用于二氧 化碳与环氧化合物的偶联反应合成环碳酸酯. 考察了离子液体结构以及温度、压力和催化剂用量等参数的影响. 结果表明, 具有 长碳链的离子液体表现出高催化活性及可重复使用性能. 离子液体的酸性影响催化活性.

关键词: 二氧化碳固定；偶联反应；酸性离子液体；环碳酸酯；哈米特酸度

收稿日期: 2014-08-11. 接受日期: 2014-09-15. 出版日期: 2015-03-20.

*通讯联系人. 电话: (0310)8578760; 传真: (0310)6025698; 电子信箱: changt03@sina.com

通讯联系人. 电话: (0931)8912585; 传真: (0931)8912582; 电子信箱: hwjing@lzu.edu.cn

基金来源：河北省自然科学基金(B2012402001); 国家自然科学基金(51202054, 21173106).

本文的英文电子版由Elsevier出版社在ScienceDirect上出版(http://www.sciencedirect.com/science/journal/18722067). 